EESTI NSV TEADUSTE AKADEEMIA TOIMETISED 1954. III kd., nr. 3

ИЗВЕСТИЯ АКАДЕМИИ НАУК ЭСТОНСКОИ ССР, 1954, ТоМ III, № 3

\title{
EESTI MUSTAKIRJU KARJA TOULIS-TOODANGULISTE OMADUSTE PARANDAMINE SOVHOOSIDES
}

\section{A. ADAMSON}

Ule 300-aastase arengu kestel on eesti mustakirju tõu moodustamisel kasutatud peale imporditud loomade kohapealse paljundamise rohkesti ka kohaliku, aborigeense karja vältavat ristamist. Nende ristluste ja kohalike looduslike ning majanduslike tingimuste koosmõjul on välja kujunenud eesti mustakirju kari tema praegusel kujul.

Veisekasvatuse arendamisel sōjajärgsel perioodil on Eesti NSV sovhoosides tunduvalt suurenenud veiste arv ja tõusnud nende produktiivsus. Eesti mustakirju tõugu veiste arv tõusis 1953. aastaks võrreldes sõjajärgse 1945. aastaga ligi 5-kordseks. Veiste tõugudest oli sovhoosides 1952. aastal boniteerimise andmeil eesti mustakirju tõugu veiseid $31,2 \%$, eesti punast tõugu $65,6 \%$ ja eesti maatõugu $3,2 \%$.

Tõuveised moodustasid eesti mustakirju karjaga sovhoosides veiste üldarvust 1945 . aastal $88,3 \%$ ja 1952 . aastal $99,0 \%$. Samuti on tunduvalt suurenenud eesti mustakirju karja puhtatõuliste veiste arv ning vähenenud parandatud veiste arv.

Tõulise kvaliteedi paranemisest tingituna tõusis eesti mustakirju karja keskmine aastapiimatoodang lehma kohta 1726 kilogrammilt 1945. aastal 4098 kilogrammile 1949. aastal. Samal ajal tõusis kõigi Eesti NSV sovhooside keskmine piimatoodang lehma kohta 1843 kilogrammilt 3878 kilogrammile.

Eesrindlikes eesti mustakirju karjaga sovhoosides, nagu Viisu, Peningi jt., on keskmine piimatoodang ühe lehma kohta aastas tõusnud üle $5000 \mathrm{~kg}$, kuna rekordilehmade toodangud on tõusnud veelgi kõrgemale. Viisu sovhoosi rekordilehm Brave $Э \mathrm{CHF}-27965$ andis 300 -päevase laktatsiooni kestel $9249 \mathrm{~kg}$.piima rasvasisaldusega $3,81 \%$, ning lehm Tiina $Э \mathrm{CHF}-28283$ andis 300 -päevase laktatsiooni jooksul $7614 \mathrm{~kg}$ piima rasvasisaldusega $3,71 \%$.

Suure piimatoodangu saavutamisel on eesmärgiks ka kõrge piimarasvasuse saavutamine. Boniteerimisandmetest selgub, et eesti mustakirju karjaga sovhooside keskmine piima rasvasisaldus on $3,63 \%$, mis on alla kehtiva riikliku standardi, kuna piimarasvasuse normiks on standardi järgi $3,7 \%$. Paremad piimarasvasuse näitajad on ainult üksikutes sovhoosides, kus teostatakse pidevalt tõuaretustööd, nagu Viisu sovhoosis, kus karja keskmine piima rasvasisaldus on püsinud $3,7-3,9 \%$ piires ning paljudel lehmadel on olnud $4,0 \%$ ja suuremgi.

Et paljudes sovhoosides on lüpsikarjal madal piimarasvasus, mis ei vasta tõu standardis püstitatud nõuetele, on seletatav sellega, et lüpsikarja- 
des on veel palju madalasse aretusklassi kuuluvaid loomi. 1952. aastal teostatud boniteerimise andmete järgi kuulus eesti mustakirju karjaga sovhoosides lüpsikarjast eliitrekord- ja eliitklassi $20,6 \%$, I klassi $38,7 \%$, II klassi

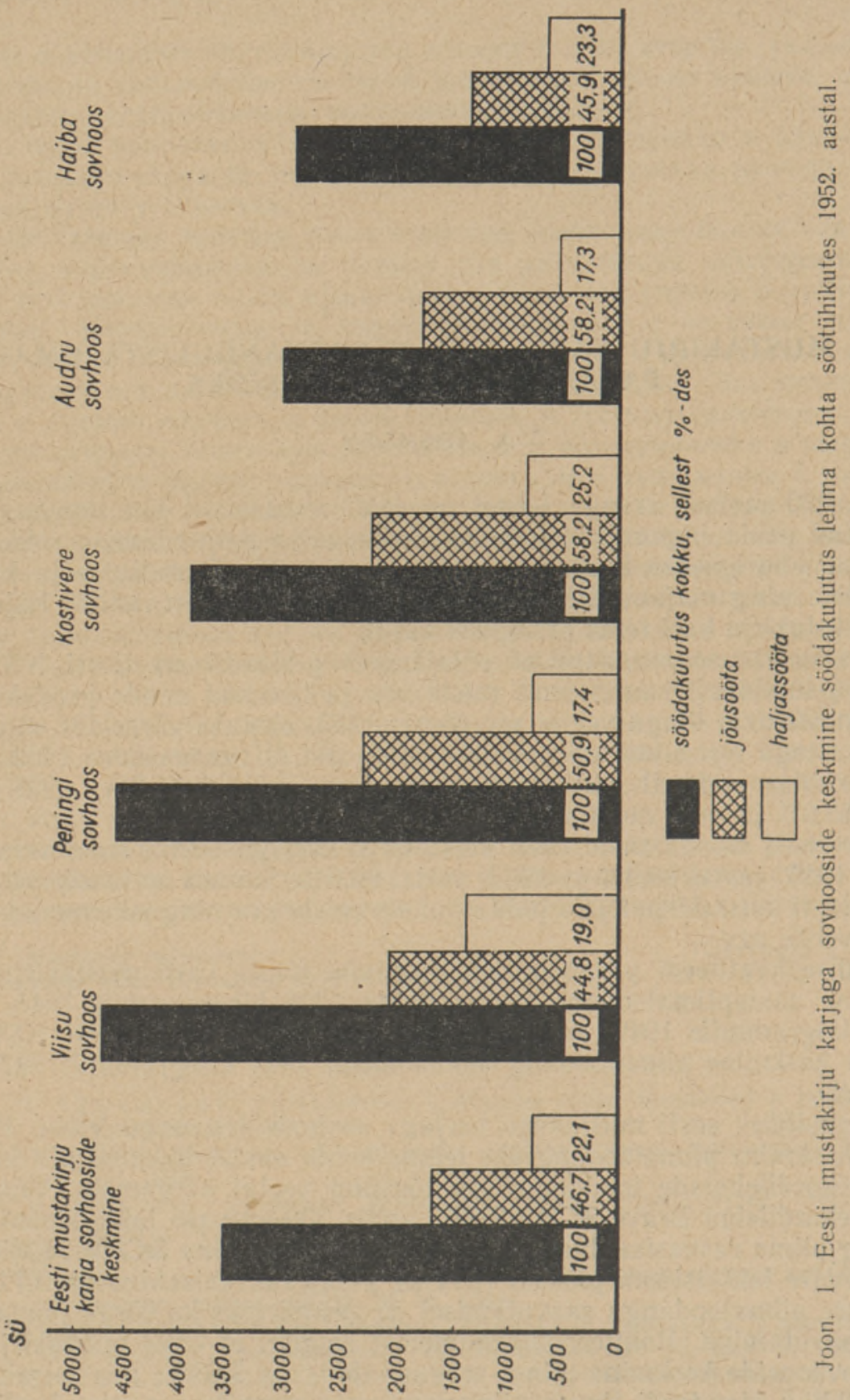

$19,5 \%$ ja väljapoole klasse $21,2 \%$. Eriti rohkesti loomi kuulub lüpsikarja koosseisust II klassi ja väljapoole klasse Sommerlingi-nimelises, Kodila, Hõreda jt. sovhoosides.

Veiste produktiivsuse tõstmisel omab esmajärgulist tähtsust eeskujulike söötmis- ja pidamistingimuste rakendamine. Eesrindlike sovhooside, nagu 
Viisu, Kostivere jt. kogemustest nähtub kujukalt, milliseid tulemusi on saavutatud söötmis- ja pidamistingimuste oskusliku rakendamisega veiste produktiivsuse tõstmisel ja tõuomaduste kujundamisel. Olevaate eesti mustakirju karjaga sovhooside 1952. aasta keskmisest söödakulutusest annab joonis 1 .

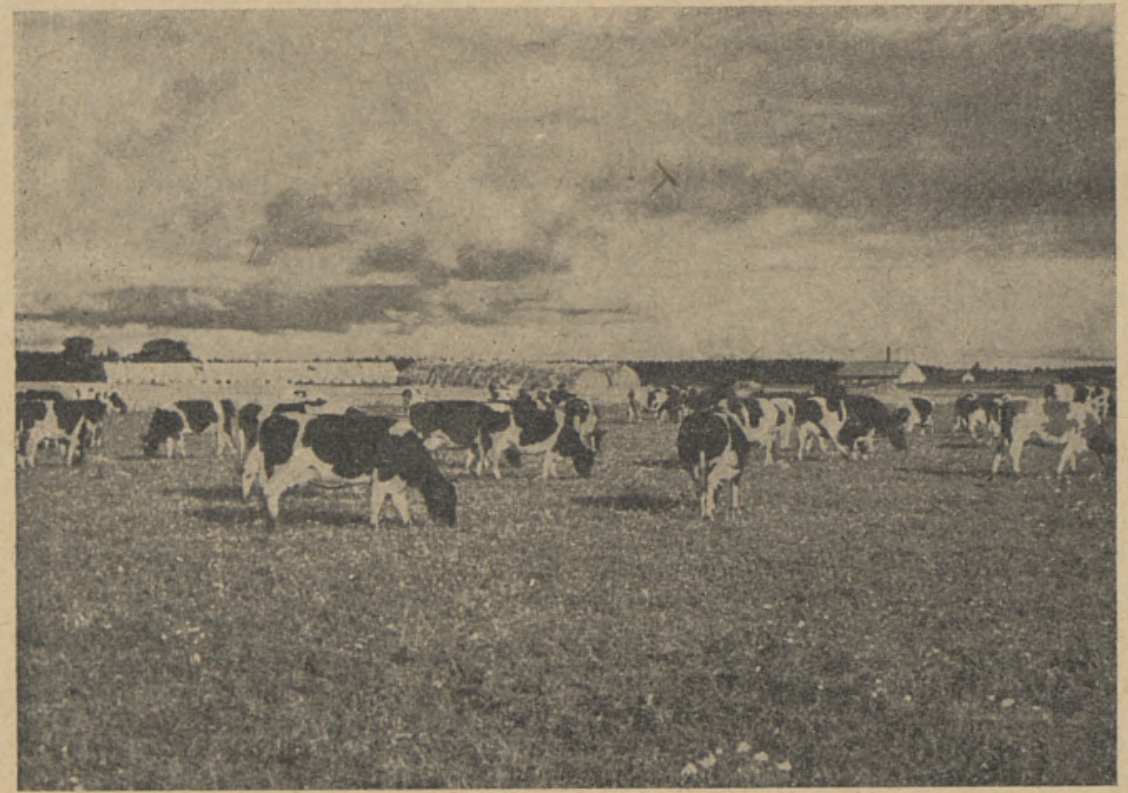

Jooṇ. 2. Viisu sovhoosi kōrgetoodanguline lüpsikari hästihooldatud kultuurkarjamaal.

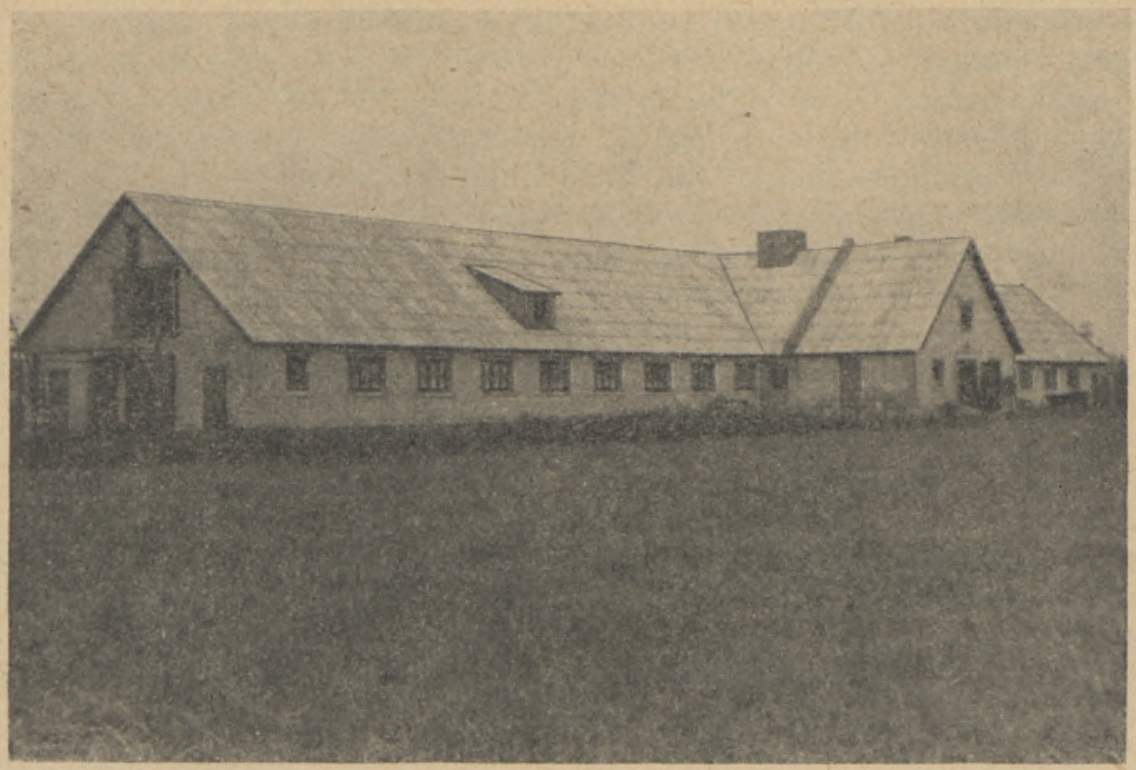

Joon. 3. Viisu sovhoosi uus veiselaut 100 loomale. 
Toodud andmetest selgub, et lüpsikarja söötmisel sovhoosides on olnud võrdlemisi suur osatähtsus jõusöötadel, mis moodustavad üldisest söödakulutusest keskmiselt $46,7 \%$, kuid suhteliselt vähe on kasutatud toorsöötasid $(13,9 \%)$ ning karjamaa- ja haljassööta $(22,1 \%)$. Söödakulutus ühe lehma kohta oli 1952. aastal keskmiselt 3000 söötühikut, millele lisandub ligi 500-600 söötühikut karjamaasööta. Kogu söödakulutus ühele lehmale küündis sovhoosides 1952. aastal keskmiselt 3600 söötühikule, millega toodeti keskmiselt $3973 \mathrm{~kg}$ piima. Lehmade eluskaal sovhoosides oli keskmiselt $510 \mathrm{~kg}$. Suurema eluskaaiuga veiseid omavad Viisu, Kostivere, Habaja ja Kurna sovhoos. Lehmade keskmine eluskaal oli Viisu sovhoosis $551 \mathrm{~kg}$, Kostivere sovhoosis $550 \mathrm{~kg}$, Habaja sovhoosis $548 \mathrm{~kg}$ ja Kurna sovhoosis $540 \mathrm{~kg}$; neis sovhoosides ulatub paljude lehmade eluskaal üle $600 \mathrm{~kg}$.

Praktilised kogemused on näidanud, et suurema eluskaaluga lehmad on võimelised kasutama suuremaid söödakoguseid ja andma suuremaid toodanguid kui väikese eluskaaluga lehmad. Viisu sovhoosis oli söödakulutus lehma kohta keskmiselt 4047 söötühikut, sellele lisandub veel 500-600 sü karjamaarohtu; sellise sööđakulutusega toodeti ühelt lehmalt keskmiselt $4870 \mathrm{~kg}$ piima. Peningi sovhoosis oli söödakulutus lehma kohta keskmiselt 4607 sü, millega toodeti $4767 \mathrm{~kg}$ piima. Mahajäänumates sovhoosides, näit. Audru sovhoosis, oli söödakulutus lehma kohta keskmiselt 3084 sü, millega toodeti ühe lehma kohta keskmiselt $3193 \mathrm{~kg}$ piima, Haiba sovhoosis toodeti 2960 söötühiku kasutamisel ühe lehma kohta keskmiselt $3541 \mathrm{~kg}$ piima ja Märjamaa sovhoosis 2621 sü kasutamisel $2628 \mathrm{~kg}$ piima.

Eesrindlike sovhooside kõrval leidub aga terve rida mahajäänud sovhoose, nagu Ubja, Audru, Niinja, Niitvälja, Haiba jt., kus veiste söötmisja pidamistingimused ei vasta nõuetele. Ebarahuldavate söötmis-pidamisolude tõttu on mainitud sovhoosides lüpsikarjal ka madal toodang.

Suure eluskaaluga ja kõrgetoodangulise lüpsikarja saamiseks on olulise tähtsusega noorkarja eeskujulik kasvatamine. Eesrindlike sovhooside, nagu Viisu, Kostivere, Saida jt. kogemused on näidanud, et noorkarja suunaval kasvatamisel valmivad noorloomad vara, muutuvad vastupidavateks ja suuretoodangulisteks. Olevaate eesti mustakirju karjaga sovhooside noorkarja arenemisest 1952. aasta boniteerimise andmeil annab joonis 4 .

Neist andmeist selgub, et eesti mustakirju karjaga sovhoosides oli keskmine eluskaal kuni 6 kuu vanustel noorloomadel $152 \mathrm{~kg}, 12$ kuu vanustel $238 \mathrm{~kg}$ ja 18 kuu vanustel $-330 \mathrm{~kg}$. Keskmised eluskaalu näitajad ei ulatu üheski vanuserühmas riikliku standardi I klassi nõueteni.

Häid tulemusi noorkarja suunaval kasvatamisel on saadud aga Viisu ja Saida sovhoosis, kus noorloomad igas vanuserühmas ületavad eliitrekordklassile kehtestatud riikliku standardi norme eluskaalu alal.

Puudulik on noorkarjakasvatus Audru, Niitvälja, Hõreda, Niinja, Ubja jt. sovhoosides, kus noorloomade eluskaal-suures enamikus ei vasta isegi riikliku standardi II klassi nõuetele.

Et paljudes sovhoosides on noorkarjakasvatus käesoleval ajal veel puudulik, pole ka nende aretuslik väärtus vajalikul tasemel. 1952. aastal teostatud boniteerimisel kuulus eesti mustakirju karjaga sovhooside lehmnoorkarjast eliitrekord- ja eliitklassi ainult $9,1 \%$, I klassi $14,4 \%$, II klassi $16,1 \%$ ja väljapoole klasse $19,1 \%$. Klassitamata jäi mitmesugustel põhjustel $41,3 \%$. Sellest nähtub, et valdavas enamikus sovhoosides on noorkarjakasvatus veel ebarahuldav, mille tõttu on vajalik tõsist tähelepanu pöörata noorloomade söötmis- ja pidamistingimuste parandamisele.

Püstitatud ülesannete täitmiseks veisekasvatuse arendamisel ja veiste produktiivsuse tõstmisel on tähtsaks teguriks nõukogude eesrindlikule mitšuurinlikule bioloogiateadusele rajaneva kompleksse tõuaretustöö raken- 
damine. Paljude eesrindlike tõuaretajate kogemustest võib järeldada, et ainult kompleksne tõuaretustöö koos eeskujulikkude söötmis-pidamistingimuste rakendamisega tagab karja produktiivsuse kiiret tõusu.

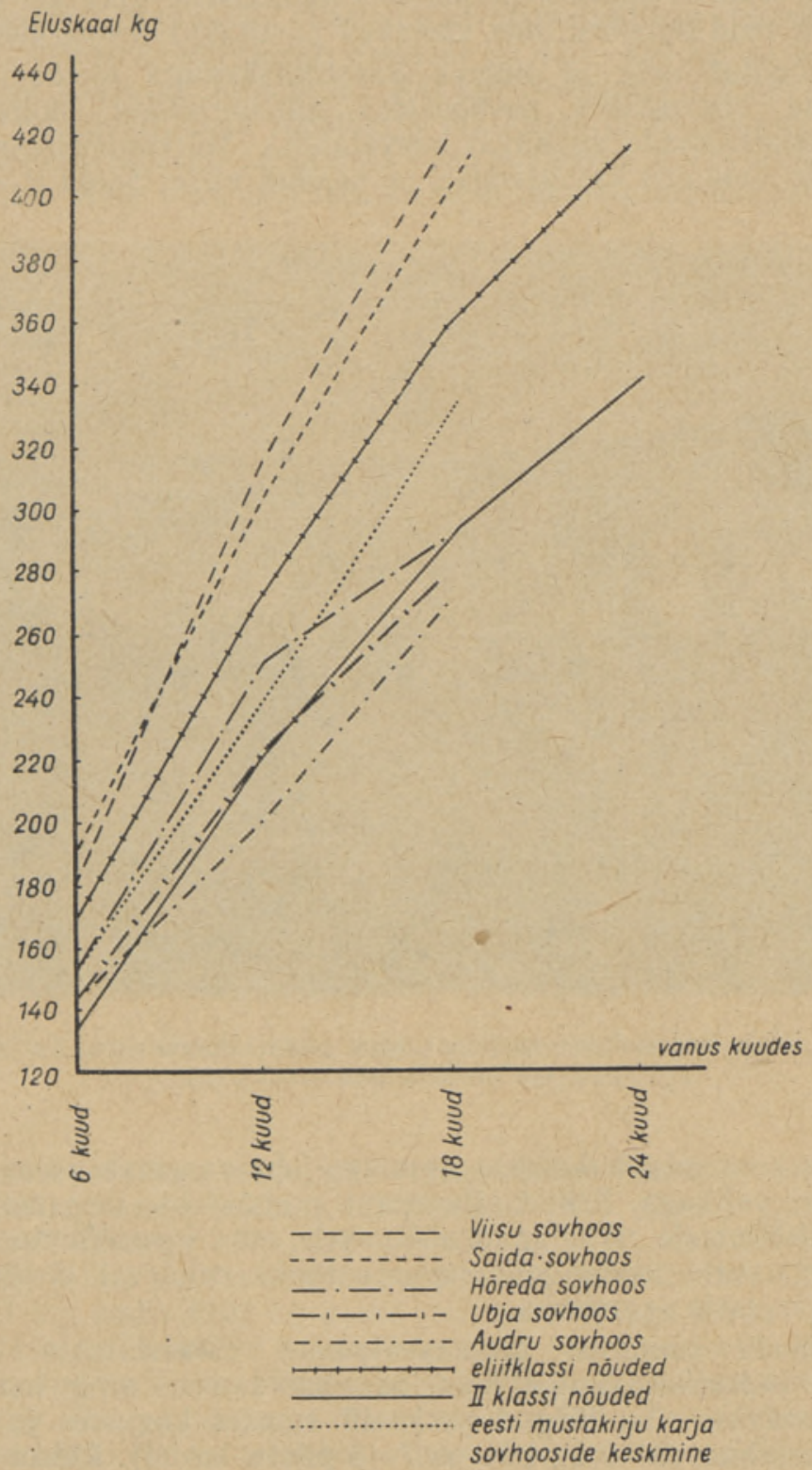

Joon. 4. Eesti mustakirju karjaga sovhooside lehmnoorkarja areng.

Teostades pidevalt suguloomade sihipärast valikut kasulike omaduste suunas, kiirendame arenguprotsessi, mis on tõu täiustamise seisukohalt otsustava tähtsusega. Akadeemik T. D. Lõssenko märgib: „Valikuta ja vastava kasvatamiseta ei oleks kunagi võinud ilmuda need loomatõud ja taimesordid, mis on loonud põllumajanduse praktika .... valiku tulemusena teostub tunnuse või omaduse tugevnemine, s. o. kujunemine" ('). 
Põhinõuded veiste valikul on, et loomadel oleks suur jõudlusvōime, tugev konstitutsioon, hea tervis ja pikk kasutusiga. Suure toodanguga piimakarja kujundamisel eelistatakse nende loomade järglasi, kes kõige paremini reageerivad headele söötmis- ja pidamistingimustele ning kel esineb kõige reljeefsemalt neid omadusi, mis vastavad püstitatud eesmärkidele.

Suure jõudlusvõime ja tugeva konstitutsiooniga loomade saamiseks rakendatakse eesrindlikes sovhoosides mitšuurinlikul bioloogiateadusel rajanevat noorloomade suunavat kasvatamist. Märkimisväärseid tulemusi noorloomade suunaval kasvatamisel on saadud Viisu, Saida jt. sovhoosides,

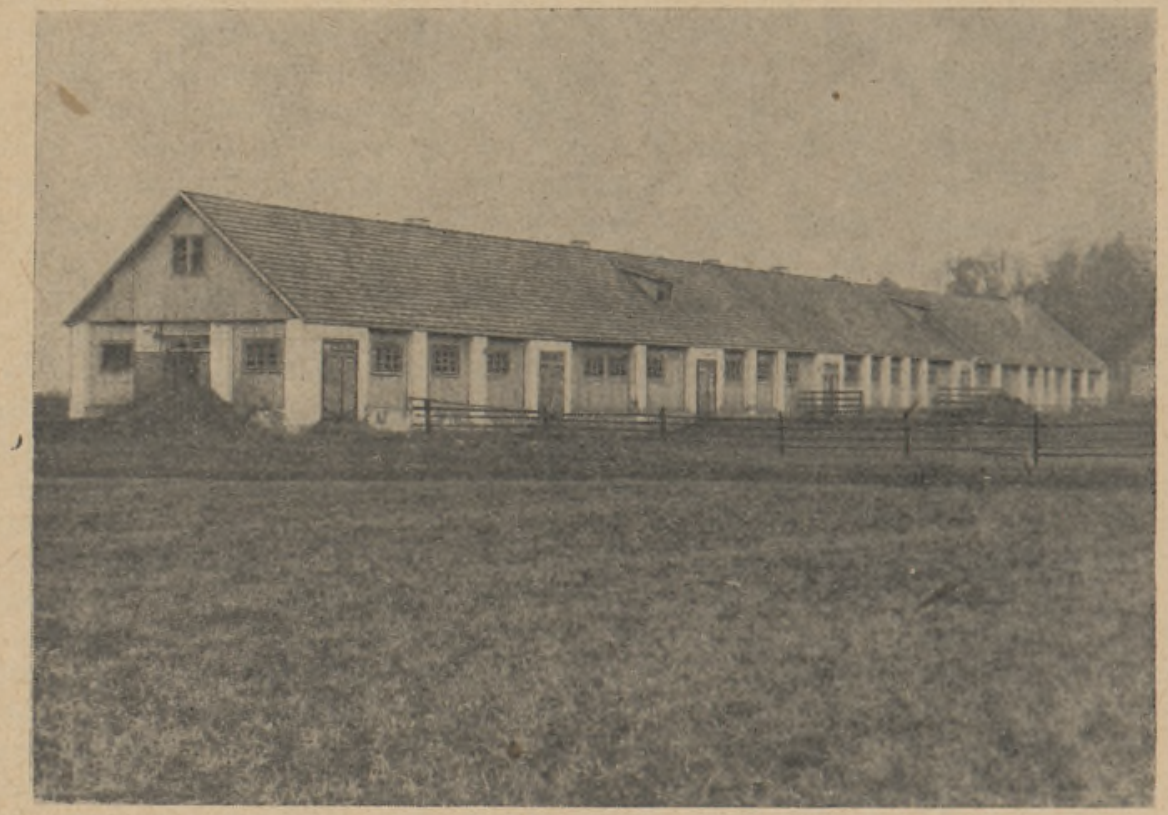

Joon. 5. Viisu sovhoosi noorkarjalaut koos profülaktooriumiga. Karjalauda ees on vasikate jooksuaed.

kus loomade arenemist hakatakse suunama juba vanemate paari - lehmade ja pullide - valikuga. Erilist tähelepanu omistatakse neis majandeis aga tiinete kinnislehmade rikkalikule söötmisele, nn. varusöötmisele kui ettevalmistusele suurte toodangute saavutamiseks eeloleval lüpsiperioodil ja elujõuliste järglaste saamiseks.

Noorloomade suunaval üleskasvatamisel rakendatakse eeskujulikke söötmis- ja pidamistingimusi koos hea hooldamise ning harjutamisega. Vasikatele antakse sünnijärgsel perioodil suurtes kogustes ja võimalikult kauem ternespiima ( $8-9 \mathrm{~kg}$ päevas $7-8$ päeva kestel). Rohke ternespiima söötmine tõstab vasikate resistentsi haiguste suhtes, kuna ternespiim sisaldab peale väärtuslike toitainete veel immuunsusaineid, Vasikate söötmise täispiimaperiood ühes lõssile üleminekuga kestab kuni 70 päeva ja lõssiperiood $6-7$ kuud ning võimaluse korral kauemgi. Eesrindlikes sovhoosides joodetakse vasikatele kogu täispiima perioodil $450-500 \mathrm{~kg}$ piima ja lõssiperioodil 1200-1400 kg lõssi. Juba varakult, esimesel võimalusel, hakatakse vasikatele andma lisasöötasid - head vitamiinheina ja sõelutud kaerajahu alates 5.-6. elupäevast, peenestatud juurvilja alates teisest elukuust ja silo alates kolmandast elukuust. Harjutamise otstarbel teostatakse talveperioodil 
noorloomade igapäevast lühemaajalist väljasjalutamist ja suveperioodil laagriviisilist pidamist koos kopliviisilise karjatamisega.

Noorloomade rikkalik söötmine ja hea hooldamine tagab nende kiire kasvu ja arenemise ning võimaldab saada terveid, tugevaid ja varavalmivaid noorloomi. Suunavalt kasvatatud lehmmullikad paaritatakse juba $18-20$ kuu vanuselt, mil nende eluskaal on $420-430 \mathrm{~kg}$, ja 2 -aastased tiined mullikad kaaluvad keskmiselt $500 \mathrm{~kg}$. Noorkarja suunav kasvatamine võimaldab tunduvalt tõsta lüpsikarja eluskaalu ja toodanguvõimet. Noorkarja suunav kasvatamine on saanud Viisu sovhoosis karja täiustamisel tähtsaks teguriks, mille tôttu noortelt, esimese laktatsiooni lehmadelt saadakse

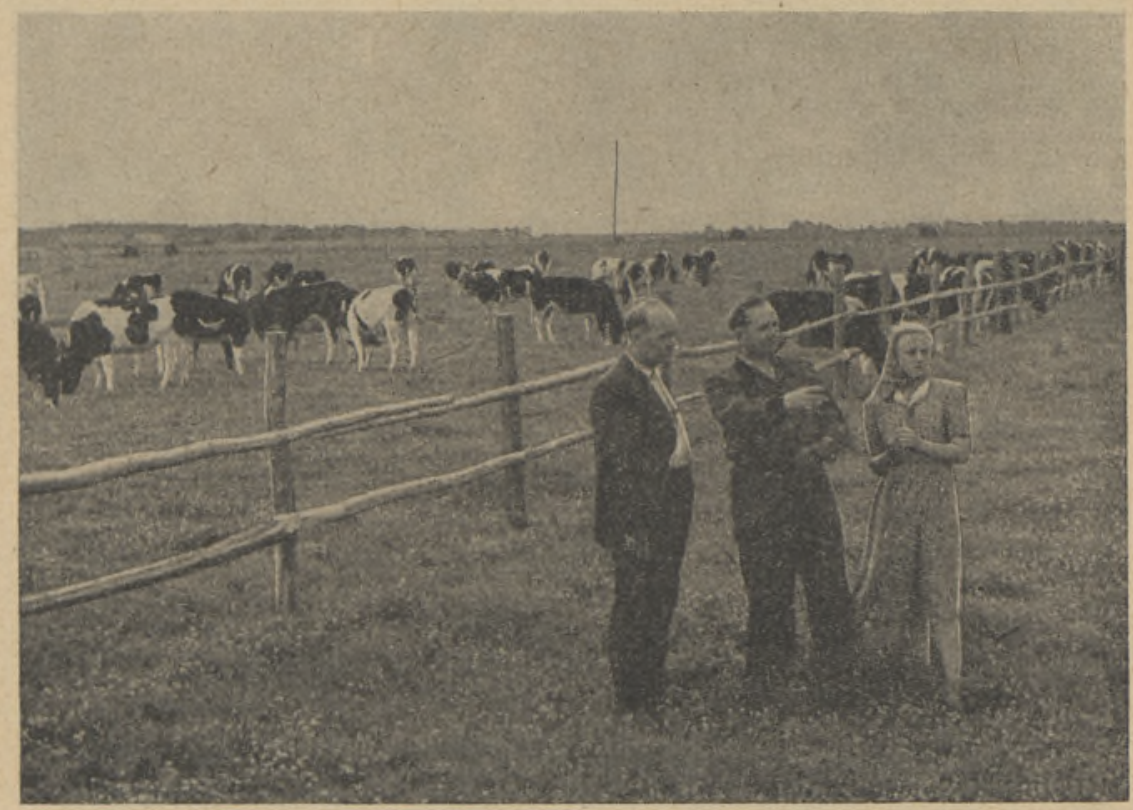

Joon. 6. Viisu sovhoosis rakendatakse suveperioodil noorkarja laagriviisilist pidamist koos kopliviisilise karjatamisega.

suure piimarasvasusega toodangut. Näiteks lehm Vanda nr. 385, kelle eluskaal oli $639 \mathrm{~kg}$, andis esimese laktatsiooni (300 päeva) jooksul $5478 \mathrm{~kg}$ piima rasvasisaldusega $4,0 \%$, Ulli $\mathrm{nr}$. 356, kelle eluskaal oli $590 \mathrm{~kg}$, samal ajal $5411 \mathrm{~kg}$ piima rasvasisaldusega $4,1 \%$ ja Amanda nr. 371 , kelle eluskaal oli $611 \mathrm{~kg}$, andis $4105 \mathrm{~kg}$ piima rasvasisaldusega $4,4 \%$.

Seoses kõrgeväärtuslike noorveiste arvu suurenemisega karjas on iga aastaga tõusnud ka Viisu sovhoosi kogu karja jõudlusvõime ning karja keskmine toodang. Peale oma karja täiendamise müüb Viisu sovhoos kõrgeväärtuslikke tõunoorloomi ka teistele sovhoosidele ja kolhoosidele, aidates sellega kaasa tõuaretustööle ka väljaspool sovhoosi.

Eesrindlike sovhooside kogemused näitavad, millised suured võimalused on kõigil sovhoosidel veiste tõuomaduste parandamisel ja produktiivsuse tõstmisel. Veiste söötmisel on vajalik suuremal määral kasutada põhisöödalist söötmisviisi, kus peamine osatähtsus langeb oma majandis toodetud söötadele ja puudujääv osa. kaetakse ostujōusöötadega. Märkimisväärseid tulemusi põhisöötade kasutamisel on Eesti NSV Teaduste Akadeemia Loomakasvatuse ja Veterinaaria Instituudi Vändra katsejaamal, kus lehmadele antakse päevas keskmiselt 10,5-11,5 söötühikut põhisöötasid. 1950. aastal 


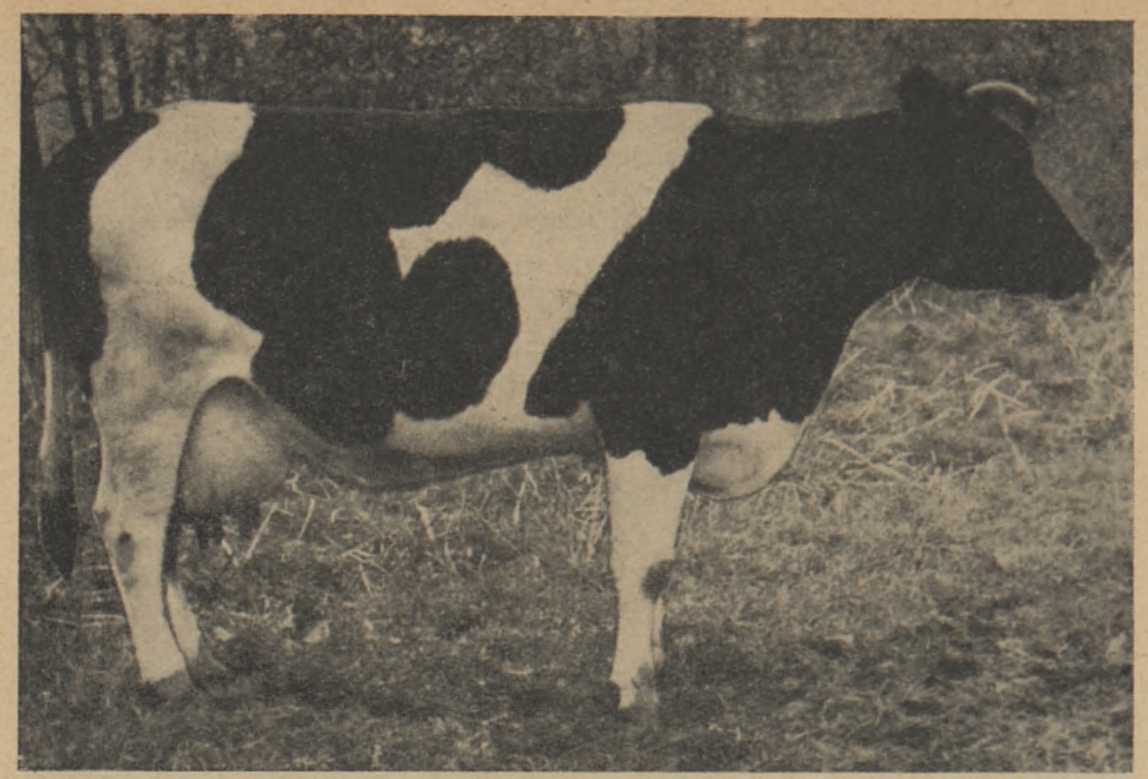

Joon. 7. Viisu sovhoosi suuretoodanguline lehin Amanda nr. 371 ЭCHF 28273 andis I lakt. (246 p.) jooksul $4105 \mathrm{~kg}$ piima rasvasisaldusega $4,4 \%$. Toodang III lakt. (300 p.) $6710 \mathrm{~kg}$ piima, rasvasus $4,2 \%$.

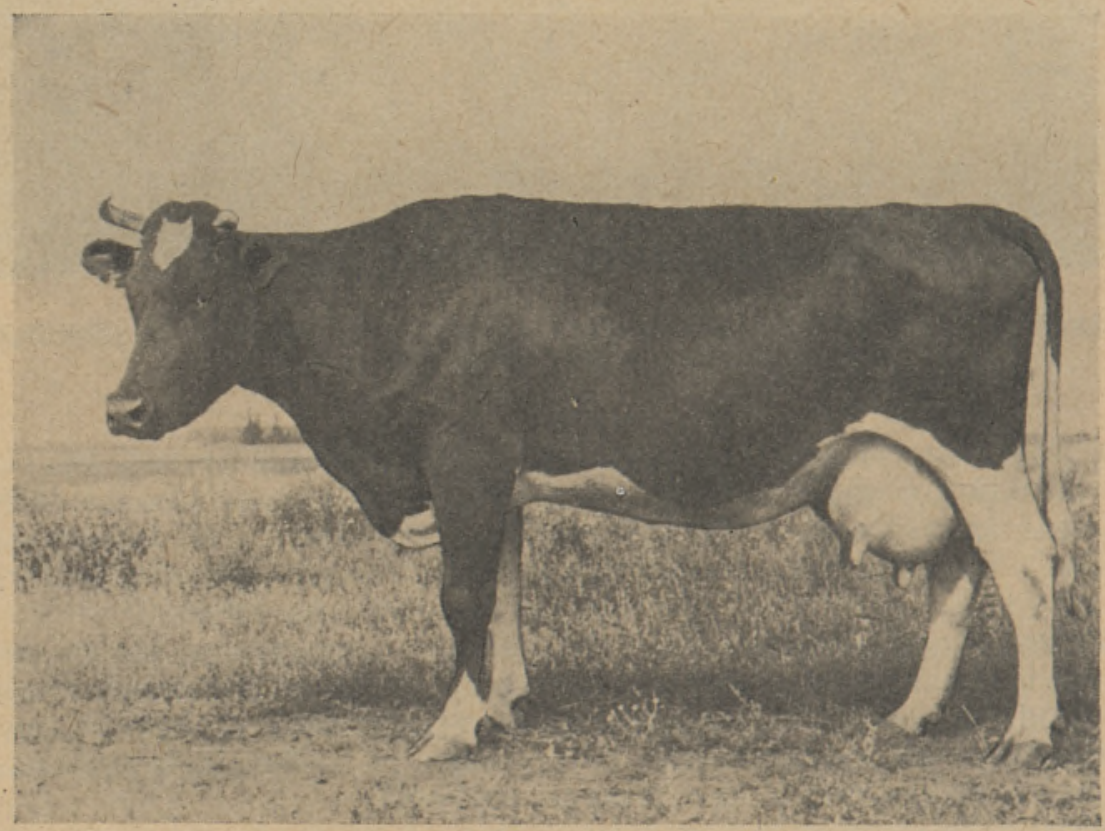

Joon. 8. Viisu sovhoosi suuretoodanguline lehm Kora nr. 347 ЭCHF -27975 andis II lakt. (300 p.) jooksul $6228 \mathrm{~kg}$ piima rasvasisaldusega $4,0 \%$.

oli seal karja keskmine piimatoodang $5667 \mathrm{~kg}$, rasvasusega $3,84 \%$, seejuures kasutati lehma kohta keskmiselt 4798 sü, sellest jõusöötasid $37,4 \%$, koresöötasid $20,9 \%$, mahlakaid ja haljassöötasid $18,0 \%$ ning karjamaarohtu $23,7 \%$. 
See näitab, et mitmekesisel ning küllaldasel söötmisel kore-, toor- ja mahlakate söötadega tõuseb lüpsikarja produktiivsus, mis võimaldab alandada ka toodangu omahinda. Uhtlasi on lüpsikarja rikkalik ja ratsionaalne söötmine aluseks loomade toodanguvõime täielikuks väljaselgitamiseks, valikuks ja pärilikkuse tugevdamiseks.

Teostades sovhoosides paremate loomade ja paaride valikut ning jättes suguloomadeks kasvama ainult väljapaistvate toodanguliste omadustega loomade järglased, moodustatakse veiste sugulusrühmad - pulliliinid ja lehmaperekonnad edasise tagajärjeka tõuaretustöö võimaldamiseks.

Liini- ja perekonnaaretuse teadliku suunamise tulemusena avalduvad järglaskonnas karakteerselt eellaste omadused, mille kaudu kujunevadki ühtlased sugulusrühmad, kes teistest sama tõugu loomadest vähem või rohkem erinevad.

Analoogiliselt liinidele on tõuaretustöös suure tähtsusega ka lehmaperekonnad. Lehmaperekondi tuleb kasutada ja uurida eriti sellepärast, et perekondades (nagu liiniski) pärilike omaduste kvaliteet kogu aeg muutub. Tekivad uued tunnused ja omadused, mis paaride valiku kaudu kinnistatakse ja pärilikkuse teel edasi antakse. Samuti põhjendatakse emasloomade perekondade uurimise vajalikkust ema suurema bioloogilise mõjuga järglastele, eriti embrüonalperioodil.

Liinide ja perekondade tähtsuse kohta märgib D. A. Kislovski, et tõu jagunemine mitmeks kvaliteedilt erinevaks liiniks ja perekonnaks on aluseks valikule ja kindlustab koos suunatud kasvatamisega tou kiiret progressi $\left({ }^{4}\right)$.

Seega on liiniaretuse sihiks teadlike aretusvõtetega pidevalt suunata tõu sugulusrühmade tõulis-toodanguliste omaduste muutumist tõusu suunas. Aretustöö eesmärgiks pole aga mitte üksnẹs rangelt säilitada olemasolevaid liine ja perekondi, vaid luua pidevalt ka uusi, kõrgema kvaliteediga, uute tunnustega liine ja perekondi, mis üha rohkem vastavad soovitud eesmärgile ning on võimelised viima muutusele tõu seniseid puudusi ja suunama tõugu hoogsa arengu teele.

Eesti mustakirju karja aretuseks kasutatavatest pulliliinidest on sovhoosides kõige enam levinud Lindberg $\mathrm{H}-2363$ liin, kes on järglastele edasi pärandanud võrdlemisi ühtlast tõutüüpi, head välimikku ja suurt toodanguvõimet. Eriti silmapaistev oli Lindberg H-2363 võime piima suure rasvasisalduse pärandamiseks. Tema 11 tütre keskmine piimatoodang oli $4910 \mathrm{~kg}$ piima $4,37 \%$-lise rasvasisaldusega, kuna tütarde emade keskmine piimatoodang oli $5024 \mathrm{~kg}$ piima $3,73 \%$-lise rasvasisaldusega. Seega pärandas ta tütardele $0,64 \%$ võrra kõrgema rasvasisaldusega piima jõudluse kui oli emadel.

Pulli Lindberg H-2363 suurepärased pärilikud omadused on ulatuslikult edasi kandunud eriti Eesti NSV Teaduste Akadeemia Loomakasvatuse ja Veterinaaria Instituudi Vändra Katsejaama kõrgaretusliku karja ja Viisu sovhoosi karja kaudu.

Senises aretustöö käigus eesti mustakirju karjaga sovhoosides kasutatud Lindberg H-2363 liini kuuluvate pullide tütarde ja nende emade tootlikkuse näitajate võrdlus on toodud joonisel 9.

Neist andmetest ilmneb, et uuritud sovhoosides on Lindberg H-2363 liini kuuluvaist pullidest väljapaistvateks osutunud Kristjan H-4704, Pennu H-3827 ja Paldur H-3395, kes on pärandanud oma tütardele suurema produktiivsuse, kui oli emadel, nii piima koguse kui ka rasvasisalduse osas. Samuti on pull Billi H-4597 ja pull Sultan H-4211 tõstvalt mõjutanud oma tütarde piima rasvasust, kuna piima rasvasisaldust on oma tütardel vähendavalt mõjutanud pullid Adolf H-4572, Lembit H-3792, Ants H-4725, Lõvi H-4001, Bill 3225 jt. 
Eriti tunduvalt on tütarde piimarasvasust vähendavalt mõjutanud pull Adolf H-4572 Sommerlingi-nimelises sovhoosis, kus tütarde piimarasvasus on keskmiselt $0,46 \%$ võrra madalam ning aasta-piimatoodang $190 \mathrm{~kg}$ väiksem kui emadel. Tütarde madala piimarasvasuse põhjusi tuleb otsida ees-
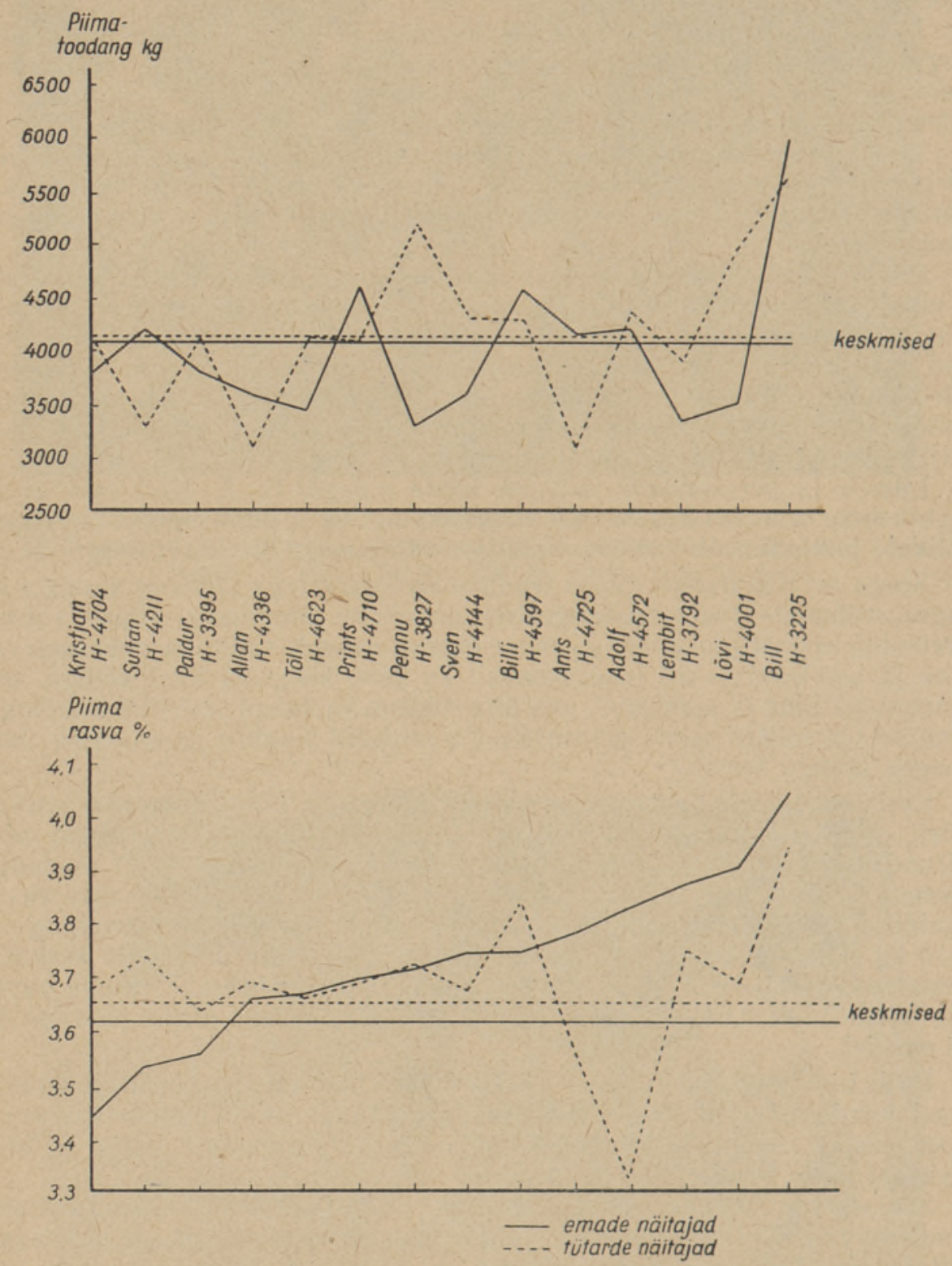

Joon. 9. Lindberg H-2363 liini kuuluvate pullide tütarde ja nende emade tootlikkuse näitajate võrdlus.

kätt puudulikust valikust ja mitte küllaldaselt headest söötmis-pidamistingimustest, mille tõttu vanemate pärilikud omadused on jäänud järglastes konsolideerumata. Pealegi pole pullil Adolf $\mathrm{H}-4572$ endal pärilikud omadused niivõrd konsolideerunud, et neid omadusi järglastele edasi pärandada, kuna tema emaema nr. $66 \mathrm{H}-12054$ piimarasvasus oli samuti madal $(3,48 \%)$ 
ja isa Billi $\mathrm{H}-3225$ tütarde keskmine piimarasvasus oli $0,09 \%$ võrra madalam kui emadel.

Lindberg H-2363 liini kuuluvate pullide tütarde konstitutsioonitüüpi iseloomustavad andmed on toodud tabelis 1. Vorrdluseks on toodud keskmised välimiku indeksid ENSV TA Loomakasvatuse ja Veterinaaria Instituudi Vändra katsejaama karja kui soovitud tüübi kohta.

Tabel 1

Andmed Lindberg H-2363 liini kuuluvate pullide tütarde konstitutsioonitüübi iseloomustamiseks

\begin{tabular}{|c|c|c|c|c|c|c|c|c|}
\hline & \multicolumn{8}{|c|}{ Pullide tütarde välimiku indeksid } \\
\hline & Kaalu & Pikkuse & $\begin{array}{l}\text { Kompakt- } \\
\text { suse }\end{array}$ & $\begin{array}{c}\text { Massiiv- } \\
\text { suse }\end{array}$ & Rinna & $\begin{array}{l}\text { Rinna- } \\
\text { laudja }\end{array}$ & $\begin{array}{l}\text { Kōrge- } \\
\text { jalgsuse }\end{array}$ & $\begin{array}{l}\text { Luus- } \\
\text { tiku }\end{array}$ \\
\hline $\begin{array}{l}\text { Bill H-3225 } \\
\text { Adolf H-4572 } \\
\text { Kristjan H-4704 } \\
\text { Billi H-4597 } \\
\text { Paldur H-3395 } \\
\text { Pennu H-3827 } \\
\text { ENSV TA LVI } \\
\text { Vändra katsejaama } \\
\text { keskmine (võrd- } \\
\text { luseks) }\end{array}$ & $\begin{array}{l}482 \\
431 \\
440 \\
478 \\
445 \\
435\end{array}$ & $\begin{array}{l}120 \\
119 \\
121 \\
119 \\
122 \\
123\end{array}$ & $\begin{array}{l}128 \\
123 \\
123 \\
127 \\
124 \\
122\end{array}$ & $\begin{array}{l}155 \\
147 \\
149 \\
152 \\
152 \\
150\end{array}$ & $\begin{array}{l}66 \\
65 \\
67 \\
71 \\
68 \\
61\end{array}$ & $\begin{array}{l}122 \\
111 \\
114 \\
113 \\
112 \\
126\end{array}$ & $\begin{array}{l}47 \\
44 \\
46 \\
46 \\
44 \\
44\end{array}$ & $\begin{array}{l}15 \\
15 \\
15 \\
15 \\
15 \\
15\end{array}$ \\
\hline
\end{tabular}

Andmeist selgub, et konstitutsioonitüübilt paremad kaaluindeksid on pullide Bill H-3225 ja Billi H-4597 tütardel. Kompaktsuse suhtes on paremad näitajad pullide Bill H-3225, Billi H-4597 ja Paldur H-3395 tütardel.

Eeltoodud andmeid arvestades võib öelda, et konstitutsioonilt enam Vändra katsejaama eesti mustakirju karja soovitud tüübile vastavaid järglasi on andnud Paldur H-3395 Peningi sovhoosis, Bill H-3225 Viisu sovhoosis, Pennu H-3827 Kostivere sovhoosis, Billi H-4597 Habaja sovhoosis ja Kristjan H-4704 Kostivere sovhoosis.

Teiseks levinumaks liiniks eesti mustakirju karjaga sovhoosides on pulli Marius-Roland H-1595 liin, kelle pärilikud omadused on märkimisväärsed, eriti välimikuliste omaduste, piimajõudluse ja piimarasvasuse parandamisel. Tema 19 tütre keskmine toodang oli $4183 \mathrm{~kg}$ piima 3,7\%-lise rasvasisaldusega, mis ületab $0,17 \%$ võrra nende emade piima rasvasisalduse.

Marius-Roland H-1595 liini kuuluvate levinumate pullide tütarde ja nende emade tootlikkuse näitajad on toodud joonisel 10 .

Andmeist selgub, et märgatavalt on tütarde piimarasvasust ja piimajõudlust tõstvalt mõjutanud pull Poiss H-3948 Kostivere sovhoosis ja pull Hans H-3369 Kurna sovhoosis. Nii on pull Poiss H-3948 pärandanud oma tütardele $0,2 \%$ võrra suurema piimarasvasuse ja pull Hans $\mathrm{H}-33690,3 \%$ võrra suurema kui oli emadel.

Piimarasvasust ja piimajõudlust on oma tütardel vähendavalt mõjutanud Kehra sovhoosi pull Vaabu H-4238 ja Viisu sovhoosi pull Leemet H-4458.

Järgmiseks levinumaks pulliliiniks eesti mustakirju karjaga sovhoosides on Pärt H-2505, kelle pärilikud omadused on eriti hinnatavad suure piimajõudluse ja piimarasvasuse osas. Liinialustaja oli hea välimikuga, laia ja tugeva kehaga ning sügava rinnaga, millised omadused ta on pärandanud edasi ka oma järglastele. Tema 17 tütre keskmine toodang oli $4308 \mathrm{~kg}$ piima $3,9 \%$-lise rasvasisaldusega.

Pärt H-2505 liini kuuluvate levinumate pullide tütarde ja nende emade tootlikkuse näitajad on toodud joonisel 11 . 
Neist andmeist selgub, et piimarasvasust on oma tütardel tôstvalt mõjutanud Viisu sovhoosi pull Pärgel H-4202 ja Kurna sovhoosi pull Pärtel H-3822. Piimarasvasust ja piimajõudlust on oma tütardel tõstvalt mõjutanud ka Habaja sovhoosi pull Prints H-3823.
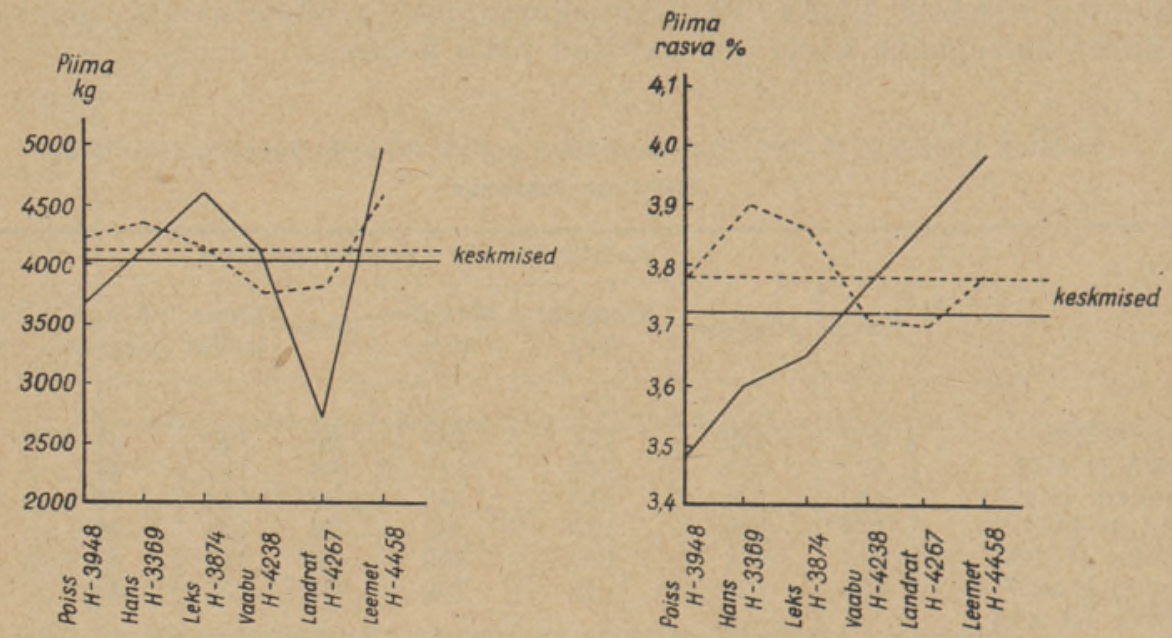

- emade näitajad -..--tütande näitajad

Joon. 10. Marius-Roland H-1595 liini kuuluvate pullide tütarde ja nende emade tootlikkuse näitajate võrdlus.
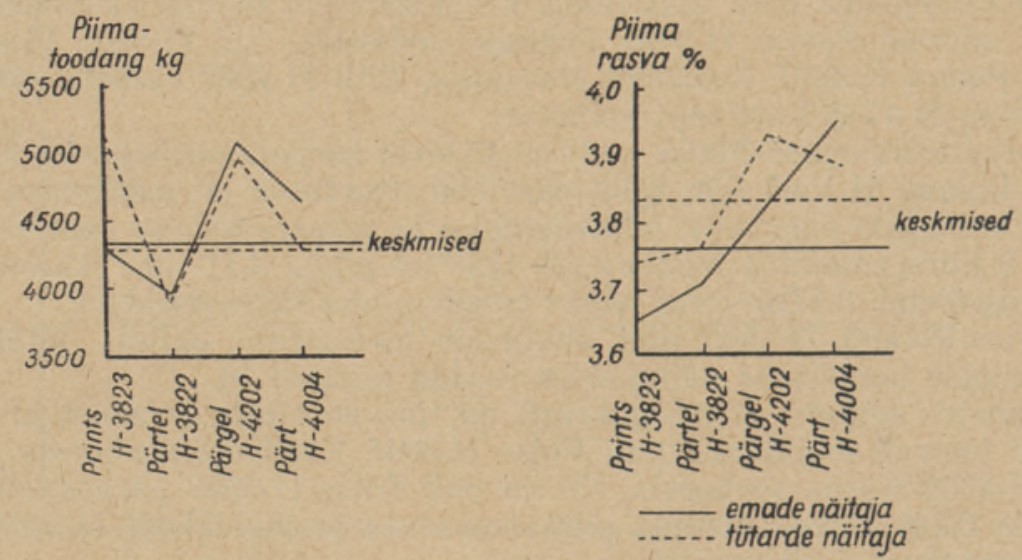

Joon. 11. Pärt H-2505 liini kuuluvate pullide tütarde ja nende emade tootlikkuse näitajate võrdlus.

Piimarasvasust ja piimajõudlust on oma tütardel vähendavalt mõjutanud pull Pärt H-4004 ning piimarasvasust on tõstnud pull Prints H-4469 Hõreda sovhoosis.

Mainitud liinijätkajad põlvnevad kõrge jõudlusvõimega esivanematest ja nende esialgne pärilikkude omaduste analüüs on teostatud valdavas enamikus nende I ja II laktatsiooni lüpsvate tütarde produktiivsuse andmeil. Et söötmis-pidamisolud mainitud sovhoosides olid sel ajal veel ebarahulda- 
vad, mis tingis madalama produktiivsuse, siis edaspidisel söötmis-pidamistingimuste parandamisel võib nende lehmade produktiivsus veelgi tốusta.

Ulatuslikult on eesti mustakirju karjaga sovhoosides aretuseks kasutatud ka Atleet $\mathrm{H}-2385$ liini heade pärilikkude omadustega piimajõudluse, piima rasvasuse ja ka kehaehituse osas. Tema 23 tütre keskmine toodang oli $4255 \mathrm{~kg}$ piima $3,83 \%$-lise rasvasisaldusega.

Atleet $\mathrm{H}-2385$ liini kuuluvate pullide tütreid võrreldakse nende emadega tootlikkuse näitajate osas joonisel 12 .

Toodud andmetest ilmneb, et piimarasvasust ja piimajõudlust on oma tütardel tõstvalt mõjutanud Viisu sovhoosi pull Atleet H-4042 ja Kodila sovhoosi pull Adam H-4467.
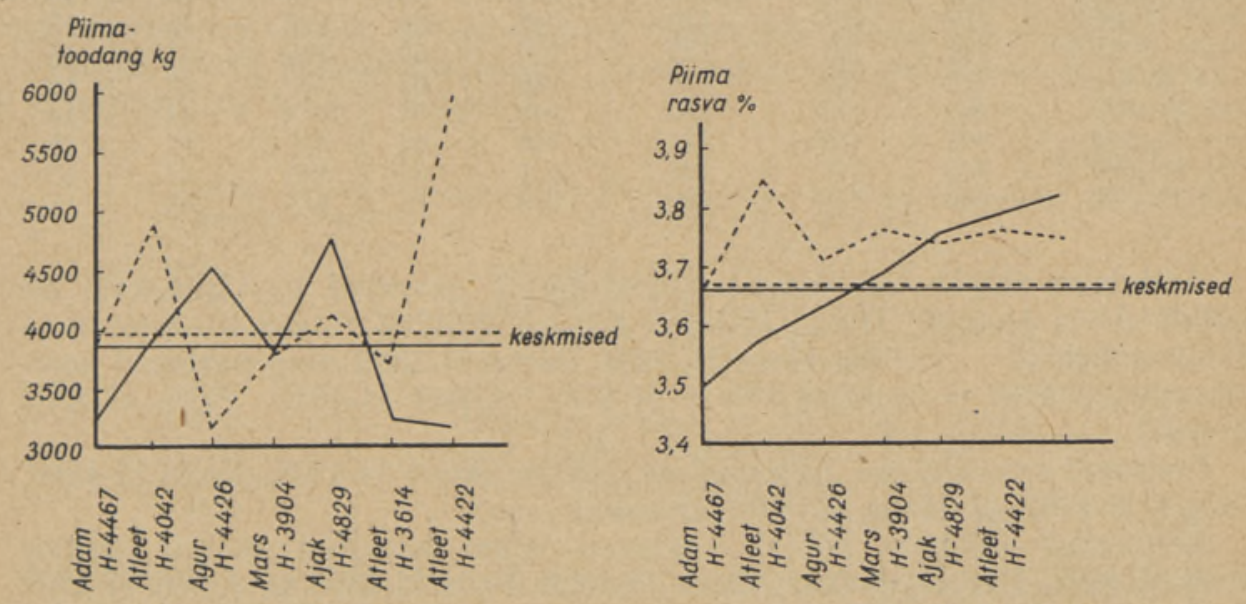

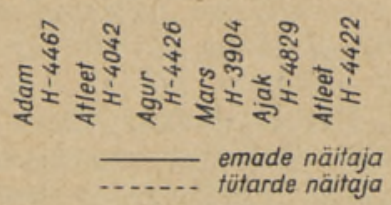

Joon. 12. Atleet H-2385 liini kuuluvate pullide tütarde ja nende emade produktiivnäitajate võrdlus.

Piimajoudlust on tõstvalt, kuid piima rasvasust vähendavalt mõjutanud oma tütardel Viisu sovhoosi pull Atleet $\mathrm{H}-4422$ ja Höreda sovhoosi pull Atleet $\mathrm{H}-3614$.

Piima rasvasust on mõjutanud tõstvalt, kuid piimajõudlust vähendavalt oma tütardel pull Mars H-3904 Ubja sovhoosis ja pull Agur H-4426 Hõreda sovhoosis.

Teistest pulliliinidest on eesti mustakirju karja aretuseks kasutatud Roland H-1053 liini esindajaid, milliseid leidub veel üksikutes majandites. Roland H-1053 liini iseloomustab suur piimajõudlus ja head välimikulised omadused. Tema 55 tütre keskmine toodang oli $5300 \mathrm{~kg}$ piima 3,65-protsendilise rasvasisaldusega.

Selle liini tähtsamaid esindajaid on Peningi sovhoosi pull Prints $\mathrm{H}-4566$,

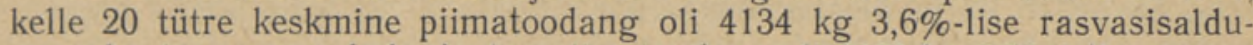

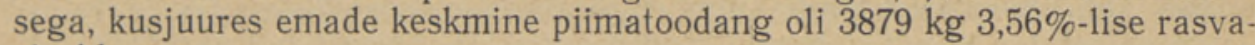
sisaldusega.

Uutest pulliliinidest on kujunemas Alvri H-4596 liin Habaja sovhoosis,

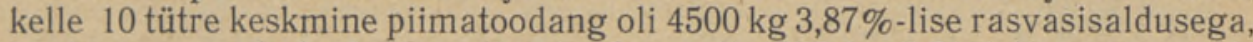

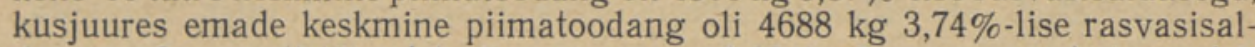
dusega. Seega oli tütardel piima rasvasus $0,13 \%$ võrra suurem kui emadel.

Eelmainitud tähtsamate pulliliinide esindajate tütarde konstitutsioonitüübi iseloomustavad välimiku indeksid on esitatud tabelis 2 . 
Tabel. 2

Eesti mustakirju karja tähtsamate pullide tütárde konstitutsioonitüüpe iseloomustavaid indekseid

\begin{tabular}{l|c|c|c|c|c|c|c|c}
\hline & \multicolumn{7}{|c}{ Pullide tütarde valimiku indeksid } \\
\cline { 2 - 8 } & Kaalu & Pikkuse & $\begin{array}{c}\text { Kompakt- } \\
\text { suse }\end{array}$ & $\begin{array}{c}\text { Massiiv- } \\
\text { suse }\end{array}$ & Rinna & $\begin{array}{c}\text { Rinna- } \\
\text { laudja }\end{array}$ & $\begin{array}{c}\text { Kõrge- } \\
\text { jalgsuse }\end{array}$ & $\begin{array}{c}\text { Luus- } \\
\text { tiku }\end{array}$ \\
\hline & & & & & & & & \\
Poiss H-3948 & 430 & 119 & 127 & 147 & 62 & 123 & 44 & 15 \\
Hans H-3369 & 444 & 124 & 122 & 150 & 70 & 106 & 43 & 15 \\
Vaabu H-4238 & 433 & 121 & 123 & 148 & 64 & 123 & 46 & 14 \\
Pärtel H-3822 & 412 & 123 & 120 & 148 & 66 & 113 & 44 & 15 \\
Pärgel H-4202 & 442 & 121 & 125 & 150 & 59 & 133 & 47 & 15 \\
Atleet H-4042 & 425 & 118 & 126 & 150 & 62 & 130 & 48 & 15 \\
Ajak H-4829 & 393 & 121 & 119 & 143 & 64 & 113 & 44 & 14 \\
Mars H-3904 & 391 & 121 & 121 & 145 & 65 & 122 & 47 & 15 \\
Frits H-4566 & 435 & 121 & 125 & 151 & 66 & 115 & 45 & 15 \\
Alvri H-4596 & 486 & 120 & 127 & 153 & 70 & 114 & 45 & 15 \\
& & & & & & & &
\end{tabular}

Andmeist selgub, et konstitutsioonitüübilt paremad kaaluindẹsid on pullide Alvri H-4596, Hans H-3369, Pärgel H-4202 tütardel. Suuremad pikkuseindeksid - pullide Hans H-3369, Pärtel H-3822 ning paremad kompaktsuseindeksid - pullide Alvri H-4596, Atleet H-4042, Frits H-4566 tütardel.

Paremad massiivsusé näitajad on pullide Alvri H-4596, Frits H-4566, Pärgel H-4202 ja Hans H-3369 tütardel.

Eeltoodud andmete põhjal vastavad enam soovitud tüübile pullide Alvri H-4596, Pärgel H-4202, Hans H-3369, Frits H-4566 ja Atleet H-4202 järglased, kellel pärilikud omadused on paremini välja kujunenud.

Kuna üksikute liinialustajate mõju järglastele pikapeale väheneb, sest väliskeskkonna tingimused muutuvad pidevalt, môjutades järglaste pärilikkust, on otstarbekohane kasutada suhteliselt lühemaid liine, mis kestavad 3-4 põlvkonda. Liinialustaja mõju saab vaid mainitud piirides lugeda enam-vähem reaalseks.

Sellest lähtudes on vajalik uuteks liinialustajateks sovhoosides lugeda pulle Kristjan H-4704 ja Poiss H-3948 Kostivere sovhoosis, Kaim H-4669 ja Pärgel H-4202 Viisu sovhoosis, Hans H-3369 Kurna sovhoosis ja Alvri H-4596 Habaja sovhoosis.

Liinide säilitamise otstarbel on vajalik rakendada teadlikku ja plaanikindlat valikut, mida pole eesti mustakirju karjaga sovhoosides seni küllalt teostatud. Akadeemik M. I. Ivanov mainib, et liin omab suurt tähtsust tõuaretuses sel juhul, kui see põlvneb isaloomast, kes on hea genotüübiga ja kui aretusvaliku või sugulusaretuse kaudu seda genotüüpi kinnistatakse ja hoitakse antud liinis. Sugulusaretus viib loomade elujõu langusele, mis tingib sugulusaretuses mitte lähissuguluse, vaid kaugema suguluse kasutamise alates III-IV põlvkonnast. Sugulusaretuse kasutamisel ähvardab karja ülearenemine, konstitutsiooni ja kehaehituse nõrgenemine jne. Seepärast peab sugulusaretusega olema ettevaatlik ja seda kasutama esialgu ainult vähestes karjades, kus on rakendatud eeskujulikud söötmis-pidamistingimused $\left({ }^{3}\right)$.

Kuid sugulusaretuseta pole alati võimalik edu saavutada. Stalini preemia laureaat K. D. Filjanski märgib, et sugulusaretusel tuleb kasutada üksnes häid külgi ja kui mitte täielikult kõrvaldada, siis igal juhul viia miinimumini tema negatiivsed küljed. Sugulusaretuseks tuleb kasutada ainult väga piiratud hulka teadlikult valitud loomi. Pärast seda, kui lii- 
nid on karjas küllaldaselt konsolideerunud, võib üles tõsta teise, mitte vähem olulise ülesande - liinidevahelise ristlusega saada uusi, veel rohkem majanduslikult tähtsate toodanguliste omaduste koondamist, et kindlustada edasine karja progress, tema produktiivsuse tõus $\left({ }^{5}\right)$.

Eeltoodust lähtudes on vajalik organiseerida sovhoosides liinide puhasaretust ja liinidevahelist ristamist, et kõrvaldada eeskujulikes karjades omavahelise suguluse tekkimist. Liinide puhasaretus toimuks seega väga vähestes majandites ning ainult eeskujulikes karjades, kus pole karta loomade elulisuse langust ega konstitutsiooni nörgenemist. Selliste majanditena sobiksid järgmised eesti mustakirju karjaga sovhoosid: Viisu, Kostivere, Habaja, Saida, Kehra, Kohila, Kurna ja Nõmküla. Kõik teised sovhoosid teostaksid aga liinidevahelist ristamist, millega väldime liinide puhasaretusel esineva sugulusega seoses olevaid võimalikke kahjulikke mõjusid.

Olemasolevate väärtuslike liinide alusel on liinide puhasaretust võimalik organiseerida tabel 3 kohaselt.

Tabel 3

\begin{tabular}{l|l}
\hline Sovhoosi nimetus & \multicolumn{1}{|c}{ A ret a t a va d li in i d } \\
\hline Viisu & $\begin{array}{l}\text { Lindberg H-2363, Pärt H-2505, Marius- } \\
\text { Roland H-1595, Atleet H-2385 } \\
\text { Lindberg H-2363, Marius-Roland H-1595 }\end{array}$ \\
Kostivere & Lindberg H-2363, Pärt H-2505 \\
Habaja & Lindberg H-2363, Marius-Roland H-1595 \\
Saida & Lindberg H-2363, Marius-Roland H-1595 \\
Kehra & Pärt H-2505, Marius-Roland H-1595 \\
Kurna & Pärt H-2505, Marius-Roland H-1595 \\
Nõmküla & Marius-Roland H-1595, Roland H-1053 \\
Kohila &
\end{tabular}

Nimetatud majandeis liiniaretuse läbiviimise juhtimine tuleb allutada zootehnilisele komisjonile, kuhu kuuluksid vastava ala spetsialistid Eesti NSV Sovhooside Ministeeriumist ning Eesti NSV Teaduste Akadeemia Loomakasvatuse ja Veterinaaria Instituudist.

Liiniaretust ei tule mõista selliselt, et me siin saame läbi ühe liiniga, mis tingib lähissugulusaretuse, vaid siin tuleb kasutada ka liinide ühendamist liinidevahelise ristamise teel. Samuti on vajalik liiniaretusega saavutatud tulemusi massiliselt levitada kunstliku seemenduse laialdase kasuta misega.

Kõrvuti liiniaretusega tuleb lehmaperekondade aretamisel sovhoosides maksimaalselt ära kasutada ja ulatuslikult levitada suure piimajõudlusega ja kõrge piimarasvasusega lehmaperekondi.

Kujuka näite lehmaperekondade suunatud kasvatamisest annavad Viisu sovhoosi senised aretustulemused karja tõulis-taodangulise kvaliteedi tõstmisel. Viisu sovhoosi karjas on välja kujunenud kuus suuremat genealoogilist lehmaperekonda, s. o. ühtse põlvnemisega emaloomade sugulusrühma. Nendest perekondadest on välja kujundatud uusi, uue kvaliteediga sugulusrühmi, kes omavad suurt tähtsust edaspidises karja aretamise töös.

O. V. Garkavi ja E. I. Kumenko järgi moodustab perekonna teatud väljapaistvama lehma järglaskond ainult $2-3$ pölvkonna jooksul $\left({ }^{2}\right)$. Viisu karja genealoogilistel lehmaperekondadel aga võib järglaskonda lugeda veel 7-10 põlvkonnas. Samuti rōhutab mainitud autor lehmaperekonna alustaja kōrget produktiivsust. Viisu karja genealoogiliste lehmaperekondade esiemasid iseloomustab suur piimajöudlus, seejuures aga väike piimarasvasus.

Eelnevast lähtudes on vajalik aretusperekonna uueks alustajaks lugeda selline lehm genealoogilisest perekonnast, kellel on mingi eriline omadus (näit. kõrge piimarasvasus), mille poolest ta täiesti erineb eellastest, ja kes pärandab seda edasi oma järglaskonnale. 
Viisu sovhoosi väärtuslikemate aretusperekondade produktiivsuse näitajad koos järglaste arvuga on esitatud tabelis 4 .

Tabel 4

Viisu sovhoosi lehmaperekondade alustajate ja järglaste produktiivsuse näitajad

\begin{tabular}{|c|c|c|c|c|c|c|c|c|c|c|c|}
\hline \multirow{2}{*}{$\begin{array}{l}\text { Perekon- } \\
\text { na alustaja } \\
\text { nimi ja } \\
\text { tôuraama- } \\
\text { tu nr. }\end{array}$} & \multicolumn{3}{|c|}{$\begin{array}{c}\text { Perekonna alustaja } \\
\text { toodang }\end{array}$} & \multirow{2}{*}{$\begin{array}{l}\text { Elus- } \\
\text { kaal }\end{array}$} & \multirow{2}{*}{$\begin{array}{l}\text { Văli- } \\
\text { miku } \\
\text { p. }\end{array}$} & \multirow{2}{*}{$\begin{array}{l}\text { Liiniline } \\
\text { kuuluvus }\end{array}$} & \multicolumn{2}{|c|}{ Järglaste arv } & \multicolumn{3}{|c|}{ Järglaste toodang } \\
\hline & $\underset{\mathrm{kg}}{\text { piima }}$ & $\begin{array}{c}\text { piima } \\
\text { rasva } \\
\mathrm{kg}\end{array}$ & $\begin{array}{l}\text { rasva- } \\
\text { suse \% }\end{array}$ & & & & lehmi & $\begin{array}{l}\text { noor- } \\
\text { loomi }\end{array}$ & $\underset{\mathrm{kg}}{\text { piima }}$ & $\begin{array}{c}\text { piima } \\
\text { rasva } \\
\mathrm{kg}\end{array}$ & $\begin{array}{l}\text { rasva- } \\
\text { suse \% }\end{array}$ \\
\hline $\begin{array}{l}\text { Amanda } \\
\text { H-14168 }\end{array}$ & 4451 & 174 & 3,9 & 480 & 71 & $\begin{array}{l}\text { Roland } \\
\text { H-1053 }\end{array}$ & 9 & 6 & 5304 & 207 & 3,90 \\
\hline H-16090 & 6487 & 274 & 4,2 & 621 & 72 & , & 8 & 2 & 4885 & 197 & 4,03 \\
\hline H-26092 & 7950 & 294 & 3,7 & 619 & 78 & " & 8 & 4 & 4881 & 193 & 3,95 \\
\hline $\begin{array}{c}\text { H-19582 } \\
\text { Fleki }\end{array}$ & 5932 & 237 & 4,0 & 586 & 82 & $n$ & 10 & 5 & 4342 & 175 & 4,03 \\
\hline $\mathrm{H}-16922$ & 6835 & 273 & 4,0 & 622 & 84 & Vodan & 8 & 3 & 4380 & 173 & 3,95 \\
\hline $\begin{array}{c}\text { Malve } \\
\text { H-16910 } \\
\text { Malve }\end{array}$ & 6369 & 274 & 4,3 & 610 & 90 & $\begin{array}{l}\text { Achilles } \\
\text { H-1591 } \\
\text { Roland }\end{array}$ & 4 & 1 & 4330 & 170 & 3,95 \\
\hline $\mathrm{H}-16078$ & 5241 & 210 & 4,0 & 645 & 84 & $\mathrm{H}-1053$ & 9 & 5 & 5198 & 202 & 3,90 \\
\hline
\end{tabular}

Andmetest nähtub, et suuremateks aretusperekondadeks on kujunenud Brave H-19582 ja Amanda H-14168, samuti Malve H-16078 lehmaperekonnad. Suurima piimajõudlusega on aretusperekonna alustajatest Biiga H-26092 ja kõrgeima piimarasvasusega on Malve H-16910.

Lehmaperekondade kujunemisele on alus rajatud ka teistes eesrindlikumates eesti mustakirju karjaga sovhoosides, nagu Kehra, Kostivere, Habaja ja Kurna. Mainitud sovhooside karjades on lehmaperekonnad siiski veel vähesearvulised ja produktiivsuselt madalama tasemega kui Viisu sovhoosis.

Eeltoodu kinnitab, et liini- ja perekonnaaretuses peituvad suured võimalused veiste tõulis-toodanguliste omaduste parandamiseks igas karjas; neid võimalusi on vaja senisest ulatuslikumalt kasutada. Edukas tõuaretustöö sovhooside karjades pole mõeldav ilma laialdase liini- ja perekonnaaretuse kompleksse rakendamiseta. See eeldab eeskujulikku algarvestust ja karja jõudluskontrolli, mida aga seni paljudes sovhoosides kahjuks ei teostata.

Et täita partei ja valitsuse poolt püstitatud ülesanded veiste arvu ja nende tõulis-toodanguliste omaduste tõstmisel, selleks on vaja sovhoosides ulatuslikumalt rakendada nõukogude eesrindlikul zootehnikal rajanevaid tõuaretusvõtteid. Eesrindlike tõuaretusvõtete kompleksse rakendamisega ja eeskujuliku söödabaasi rajamisega on võimalik sovhoosides tõsta eesti mustakirju karja keskmine aasta-piimatoodang lehma kohta 5000-6000 kilogrammile rasvasisaldusega $3,9-4,0 \%$. Lehmade keskmine eluskaal tuleb tōsta vähemalt 600 - 650 kilogrammini ja välimiku punktide arv 85 - 90 -le.

Eesti NSV Teaduste Akadeemia

Loomakasvatuse ja Veterinaaria Instituut
Saabus toimetusse 25. I 1954 
1. T. D. L õ s se n ko, Agrobioloogia, Tartu, 1949, lk. 597.

2. О. В. Гаркави и Е. И. Кум н ко, Генеалогия и некоторые бнологические показатели стада совхоза жКараваево». Государственная племенная книга крупного рогатого скота костромской породы, том I-III. Сельхозгиз, Москва, 1950.

3. М. Ф. Ив а но в, Избранные сочинения, том I-III. Сельхозгиз, Москва, 1949-1950.

4. Д. А. Кисловски й, Разведение сельскохозяйственных животных. Сельхозгиз, Москва, 1951.

5. К. Д. Ф и л янский, Повышение продуктивности животноводства. Государственное издательство сельскохозяйственной литературы, Москва, 1949.

\section{УЛУЧШЕНИЕ ПОРОДНО-ПРОДУКТИВНЫХ КАЧЕСТВ ЭСТОНСКОГО ЧЕРНОПЕСТРОГО СКОТА В СОВХОЗАХ}

\section{А. и. АДАМСОН}

Резюме

В послевоенный период в разведении эстонского чернопестрого скота в совхозах республики достигнуты заслуживающие внимания результаты. Пополовье крупного ротатого скота увеличилось в совхозах к 1953 году по сравнению с 1945 годом почти в 5 раз. Поголовье скота эстонской чернопестрой породы составляло $31,2 \%$ от общего поголовья крупного рогатого скота, поголовье эстонской красной породы - $65,6 \%$ и эстонской местной породы - $3,2 \%$. Породность скота в совхозах, разводящих эстонский чернопестрый скот, повысилась за это же время с 88,3 до $99 \%$. Значительно увеличилось также поголовье чистопородного скота.

В связи с улучшением породных качеств скота в совхозах из года в год увеличивается также и удой коров эстонской чернопестрой породы скота, который на корову повысился с 1726 кг в 1945 году до 4098 кг в 1949 году. За этот же период средний удой на корову по всем совхозам Эстонской ССР повысился с 1844 кг до 3878 кг молока.

В передовых совхозах, как, например, «Вийсу», «Пенинги» и др., средний удой на корову превышает 5000 кг молока, а удои коров-рекордисток достигают $8000-9000$ и более килограммов молока в год.

Кроме получения высоких удоев, преследуется цель достижения высокой жирномолочности. В 1952 году средняя жирномолочность в совхозах, разводящих эстонский чернопестрый скот, составляла $3,63 \%$, т. е. была ниже государственного стандарта $(3,7 \%)$. Главными причинами низкой жирномолочности является недостаточное и одностороннее кормление и неудовлетворительные условия содержания скота.

Лучшие показатели жирномолочности наблюдаются лишь в отдельных совхозах - «Вийсу» и др., где созданы образцовые условия кормления и содержания скота и осуществляется сознательный отбор и подбор. Так, средняя жирномолочность стада совхоза «Вийсу» $-3,7-3,9 \%$, а жирномолочность отдельных коров равна $4,0 \%$ и более.

Поскольку молочные стада во многих совхозах имеют еще низкую жирномолочность, то в связи с этим большое количество животных молочного стада относится к более низкому бонитировочному классу. По данным бонитировки 1952 года, из общего поголовья молочного скота в совхозах, разводящих эстонский чернопестрый скот, к классам элитарекорд и элита относилось $20,6 \%$, к I классу - 38,7\%, ко II классу $19,5 \%$ и вне класса было $21,2 \%$ жнвотных. 
В деле повышения продуктивности крупного рогатого скота первостепенное значение имеет создание образцовых условий кормления и содержания. Опыт передовых совхозов наглядно показывает, какие результаты достигаются в деле. повышения продуктивности животных и образования их породных качеств умелым применением условий кормления и содержания.

Анализ расхода кормов в совхозах показывает, что при кормлении молочного скота сравнительно большой удельный вес имеют концентрированные корма, расход которых составляет в среднем $46,7 \%$ от общего расхода кормов. Относительно мало использовались сочные корма $(13,9 \%)$, пастбищный и зеленый корм $(22,1 \%)$. Общий расход кормов в совхозах в среднем на одну корову составлял 3000 кормовых единиц и дополнительно к этому еще $500-600$ кормовых единиц пастбищного корма.

Опыт работы совхозов показывает, что коровы, имеющие большой живой вес, способны в большей мере использовать основные корма и давать больше молока, чем коровы, имеющие низкий живой вес. По бонитировочным данным, средний живой вес коров эстонского чернопестрого скота в совхозах составлял 510 кг. Коровы с наибольшим живым весом имеются в совхозах «Вийсу», «Костивере» и «Хабая». Средний живой вес коров стада совхоза «Вийсу» - 551 кг, совхоза «Костивере» - 550 кг и совхоза «Хабая» - 548 кг.

В деле получения высокопродуктивного и отличающегося крупной величиной молочного скота в совхозах существенное значение имеет образцовое воспитание молодняка. Опыт передовых совхозов («Вийсу», «Костивере, «Сайда» и др.) показал, что при направленном воспитании молодняка выращиваемые животные отличаются скороспелостью, выносливостью и высокой продуктивностью.

По данным бонитировки 1952 года, в совхозах, разводящих эстонский чернопестрый скот, средний живой вес молодняка в 6-месячном возрасте составлял $152 \mathrm{kr}$, в 12-месячном возрасте - 238 кг и в 18-месячном 330 кг. Приведенные показатели живого веса, однако, ни в одной возрастной группе не отвечают требованиям стандарта I класса.

Ценные результаты при направленном воспитании молодняка получены в совхозах «Вийсу» и «Сайда», где молодняк в каждой возрастной группе превосходит требования стандарта, предусмотренные для класса элита-рекорд. В преобладающем большинстве совхозов воспитание молодняка все же находится еще в неудовлетворительном состоянии.

При выполнении задач, поставленных партией и правительством в деле развития скотоводства и повышения продуктивности крупного рогапого скота в совхозах, важным фактором является применение комплекса племенной работы.

Опыт передовых совхозов ( Вийсу» и др.) подтверждает, что высокие продуктивные качества крупного рогатого скота проявляются лишь там, где применяется обильное кормление и осуществляется отбор лучших животных.

При создании высокопродуктивного молочного скота следует предпочитать потомков тех животных, которые лучше всего реагируют на хорошие условия кормления и содержания и у которых наиболее рельефно выражены качества, соответствующие поставленным целям.

При помощи осуществления в совхозах отбора лучших животных и подбора родительских пар, а также оставления на племя лишь потомков, происходящих от животных с выдающимися продуктивными качествами, создаются родственные группы - линии быков и семейства коров, имеющие большое значение в совершенствовании пород животных. В резуль- 
тате сознательного управления разведением животных по линиям и семействам у потомства развиваются характерные свойства предков, которые закрепляются в потомстве, и таким образом создаются однородные родственные группы, в большей или меньшей мере отличающиеся от других животных той же породы.

Целью племенной работы является не только сохранение существующих линий и семейств, а также и создание новых линий и семейств, с новыми признаками более высокого качества, все более соответствующих поставленной цели и способных исправить прежние недостатки породы и направить ее по пути стремительного развития.

При разведении эстонского чернопестрого скота в совхозах используются в основном линии быков Линдберга Н-2363, Пярта Н-2505, Мариус-Роланда Н-1595 и Атлета Н-2383, которые передали потомкам по наследству сравнительно однородный породный тип, хороший экстерьер и высокую продуктивность.

Влияние отдельных родоначальников линий на потомков с течением времени уменьшается, так как условия внешней среды беспрестанно изменяются, оказывая воздействие на наследственность потомков. Поэтому на практике целесообразно использовать относительно непродолжительные линии, состоящие из 3-4 поколений. Влияние родоначальника может считаться более или менее реальным дишь в указанных пределах.

Исходя из этого, новыми родоначальниками линий в совхозах следует считать быков Кристьяна Н-4704 и Пойсса Н-3948 в совхозе «Костивере», Кайма Н-4669 и Пяргела Н-4202 в совхозе «Вийсу», Ханса Н-3369 в совхозе «Курна» и Альври Н-4596 в совхозе «Хабая».

При оценке по потомству упомянутых быков выявилось, что продуктивные показатели их дочерей превосходят соответствующие показатели матерей этих дочерей. Так, продуктивность дочерей быка Кристьяна Н-4704 превышала продуктивность их матерей по удою молока на 295 кг и по жирномолочности на 0,24\%. Дочери быка Пойсса Н-3948 дали молока на 575 кг больше и имели жирномолочность на $0,21 \%$ выше, чем их матери; дочери быка Ханса Н-3369 превосходили соответствующие показатели своих матерей на 251 кг и 0,3\%. Заслуживают внимания также индексы, характеризующие экстерьер и тип конституции этих дочерей.

В целях сохранения линий необходимо сознательно и планомерно применять отбор с использованием родственного спаривания при участии животных, находящихся в дальнем родстве (начиная с III-IV поколения). Поскольку при использовании родственного спаривания стаду угрожает переразвитость, ослабление конституции и телосложения, то родственное спаривание может быть допущено лишь в немногих совхозах, в которых созданы образцовые условня кормления и содержания.

Чистое разведение по линиям следовало бы проводить первоначально в немногих и лишь в образцовых совхозах, а именно - в совхозах «Вийсу», «Костивере», «Хабая», «Сайде», «Кехра», «Кохила» и «Курна». Все остальные совхозы, разводящие эстонский чернопестрый скот, осу. ществляли бы межлинейное скрещивание, что помогло бы избежать обусловленных близким родством нежелательных явлений, имеющих место при чистом - разведении по линиям. Руководство разведением по линиям в указанных хозяйствах следует возложить на соответствующую зоотехническую комиссию.

При разведении по линиям не следует ограничиваться созданием одной линии, обусловливающей родственное спаривание, но необходимо использовать также сочетание линий путем межлинейного скрещивания. Необходимо также широко распространить достигнутые в деле разведения по линиям результаты, используя искусственное осеменение. 
Наряду с разведением по линиям существенное значение имеет образование в каждом стаде семейств коров, чему не все совхозы уделяют достаточное внимание.

Наглядным примером направленного использования семейств коров могут служить результаты, достигнутые в повышении породно-продуктивных качеств скота совхозом «Вийсу». В ходе племенной работы в совхозе «Вийсу» образовались шесть более крупных и ценных семейств коров, как, например, семейство коровы Аманды Н-14168, средний удой дочерей которой составил 5304 кг молока с 3,9\% жира, и Мальве Н-16078, средний удой дочерей которой был равен 5198 кг молока.

Основа для образования семейств коров заложена и в других более передовых совхозах, разводящих эстонский чернопестрый скот, как, например, в «Кехра», «Костивере», «Хабая» и «Курна».

Все сказанное выше подтверждает, что в разведении по линиям и семействам заключены большие возможности для улучшения породно-продуктивных качеств животных в каждом стаде, но эти возможности необходимо более широко использовать.

Комплексным применением передовых приемов разведения скота и созданием образцовой кормовой базы в совхозах можно в течение ближайших лет повысить средний удой коров эстонского чернопестрого скота до 5000-5500 кг молока при содержании в нем 3,9-4,0\% жира, средний живой вес коров до $600-650$ кг, а оценку экстерьера до 85-90 баллов.

Институт животноводства и ветеринарии Академии наук Эстонской ССР 